\title{
Relative Location of Bins and Its Effects on Recycling in Campus
}

Fuat Kaan Aras ${ }^{1^{*}}$ and Can Anarat ${ }^{2}$

${ }^{1}$ Acibadem University, Atasehir, Istanbul, Turkey

${ }^{2}$ Bogazici University, Bebek, Istanbul, Turkey

*Corresponding author: Fuat Kaan Aras, School of Medicine, Acibadem University, Kayisdagi Cad. No: 32 , 34752 Atasehir/ Istanbul, Turkey, Tel: +90216 576 50 76; Email: fuat.aras@live.acibadem.edu.tr

Received date: April 01, 2016; Accepted date: May 16, 2016; Published date: May 23, 2016

Copyright: (c) 2016 Aras FK, et al. This is an open-access article distributed under the terms of the Creative Commons Attribution License, which permits unrestricted use, distribution and reproduction in any medium, provided the original author and source are credited.

\begin{abstract}
The amount of non-recyclable material in recycle-bins creates extra cost because of the extra labor required for sorting and transportation. This study aims to investigate if the problem is caused by the placement of the recyclebins. We analyzed whether basic placement changes in proximity would reduce the amount of wastes in recyclebins and also whether these changes will maximize the recyclable materials in the recycle bins, thus, helping the recycling process to be more profitable. There was a significant decrease of externally derived contamination when recycle-bins were placed further, relative to waste-bins. However, that reduced the recyclable materials also. The conclusion was placing a bin nearer to foot traffic increases its litter load. It is recommended that in places with higher amount of recyclable material, recycle-bins to be placed nearer, regardless of externally derived contamination, in order to obtain as much recyclable material as possible.
\end{abstract}

Keywords: Recycling behavior; Recycling; Recycling barriers; Recyclable material; Externally derived contamination; Littering; Waste management

\section{Introduction}

In our throw-away era in which we are depleting our resources, many countries, municipalities and local governments conduct programs for recycling and sustainable waste management. Their success is important to ensure humanity's welfare. Most waste is produced by the public, therefore public participation is important [1-3]. Public campaigns for social awareness and responsibility, technology and environmental education are the main provisions to encourage people to participate in recycling [4].

Higher education institutions are primary centers to foster the next generation's environmental consciousness and to devise and sustain proper waste management methods and practices [5-9]. Because universities generate a range of wastes different than households [10], they deserve special parameters of recycling convenience claimed that recycling is altruistic. This altruism must be encouraged by reducing its inconvenience or by compensating its cost with rewards [11-14].

The research found that situational factors are important in recycling behavior. Decreasing expended energy and time to execute a proper recycling process encourages participation in recycling $[1,15]$. Davies et al. [16] examine how control elements either facilitate or discourage recycling, and suggest better strategies for encouraging voluntary compliance with recycling procedures. Accordingly, this study is concerned to understand how placement of bins relates to recycling convenience, because removing external barriers can significantly influence the adoption and maintenance of behavior. In order to optimize placement, recycling bins must be easily accessible; they should be dispersed across a region rather than centralized in one location within that region; and they should provide for distinct kinds of refuse - at least to distinguish recyclables from rubbish [17].
Over the past few years, research has shown that use of recycling bins depends also upon waste bins, as recycling rates dramatically decrease when recycling bins are located away from waste bins. This dependency raises our main issue: externally derived contamination, i.e., placing improper wastes into recycling bins [18]. Some reasons for this error are: not knowing which materials are to be recycled, or not understanding the signs on bins or their specific meaning [19]. This research examines low-recyclers, those who think they don't have time or energy to distinguish between waste and recycling bins [20]. Perhaps such people do not think about whether their refuse is recyclable, and to just get rid of the garbage they prefer to throw it into the nearest bin regardless of its designation because it is easier. People have a significant tendency to choose the nearest location, just as they tend to select supermarkets or hospitals by their convenient location $[21,22]$. Now distance to the nearest receptacle is positively predictive of littering [23], our aim is to investigate whether placement of recycling bins, relative to foot traffic patterns and to the placement of waste bins, affects the quantity of externally derived contamination and whether these changes in placements are also predictive of littering.

\section{Method}

\section{Research site}

Observations were carried out on four different days at a health sciences university in Istanbul, with different bin placement on each day. The heterogeneity of those visiting or using the university is due to its facilities. A second division professional basketball team and their youth teams provide an athletic and non-academic population. Conference rooms used by various companies provide non-healthsector population. Also, the university's high technology devices and simulators attract companies to set up seminars for doctors; this provides a population from the health-sector outside the university. As universities don't consist only of students, naturalistic observation method was used, including all guests to the university. The campus has two main buildings; the observed bins were located in a passage 
Page 2 of 4

between the buildings and the cafeteria. This is the most heavily used walkway of the campus.

\section{Project design}

Given the corridor of the walkway, foot traffic was on the $\mathrm{x}$ axis. On day one, waste bins were placed in front of recycle bins on the y axis (Figure 1); on day two, their relative placement was reversed (Figure 2).
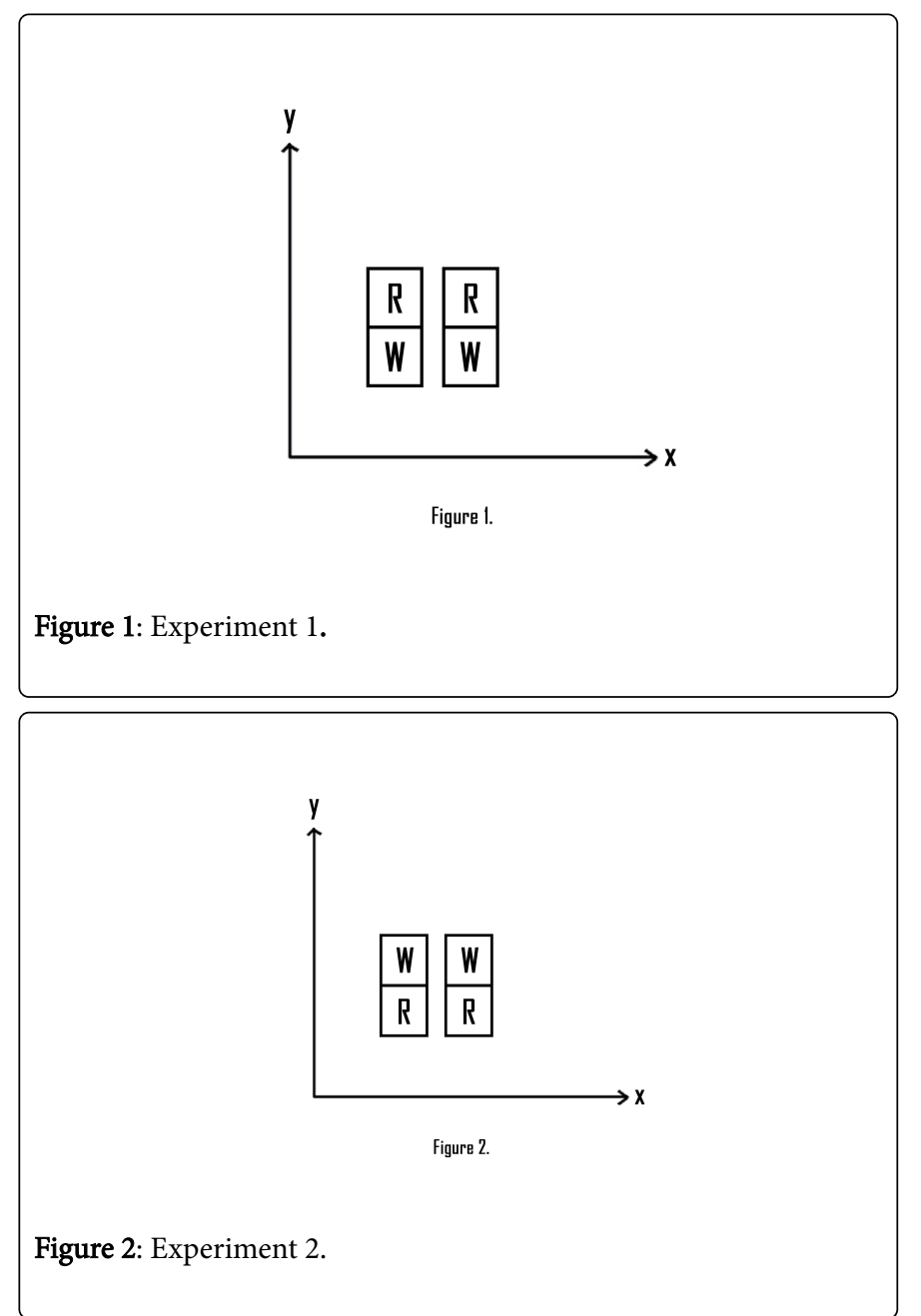

Though $71 \%$ of people don't change their recycling attitude by social pressure [19], because participants desire to present themselves in a positive way [24] and because participants' choices change by the status, age, race or gender of the interviewers [25-28], the authors posed as coffee shop customers, observing from $10 \mathrm{~m}$ distance to avoid creating social pressure.

Administrators, staff, students and visitors were observed unawares at the university, in Istanbul, between 9 A.M. and 4 P.M. Experiments were conducted on Fridays between 13 November and 11 December 2015. Bins were emptied at 12:30 p.m. by staff as usual, to avoid fullness as a confounding factor so that people wouldn't change their bin preference when they saw one bin much more full than the other. Bins which were regularly used in the observed area were identical except for the recycle sign on top of recycle bins and non-recycle sign on top of waste bins.
On day three, recycling bins were placed on the $\mathrm{x}$ axis and waste bins were placed between them (Figure 3 ).

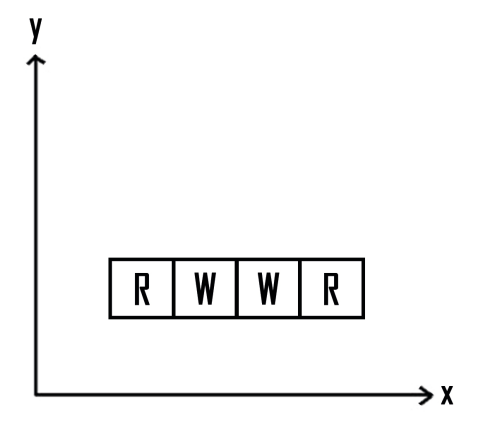

Figure 3.

Figure 3: Experiment 3.

On day four, their respective locations were reversed, placing recycling bins between waste bins on the $\mathrm{x}$ axis (Figure 4).

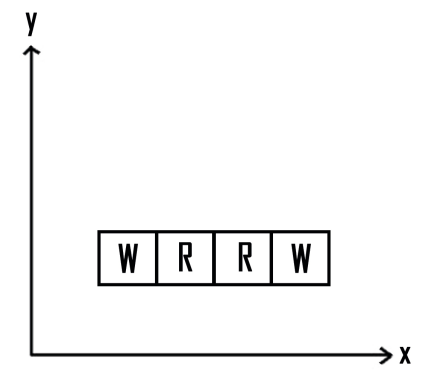

Figure 4.

Figure 4: Experiment 4.

\section{Data recording and analysis}

At least one of the authors was always observing the bins during the process to record data at the moment someone threw material into the bins. Placement of bins was manipulated only on days of observation; after observation, bins were returned to their original positions. The system - developed by the Society of the Plastics Industry to aid sorting for recycling - was used to classify types of litter. It was calculated that 12 observations would be needed in each group to give the study a power of 80 percent to detect a difference in primary outcome of 75 versus 25 percent $p<0.05$ was accepted as a significant level.

\section{Results and Discussion}

Approval was obtained from the first author's university's Human Research Ethics Committee on 20 August 2015 and from the second 
author's university's Human Research Ethics Committee on 17 August 2015. The fullness of bins never exceeded 2/3. Day two's experimental design significantly increased the amount of recyclable material obtained and slightly increased the externally derived contamination (Tables 1 and 2). The difference between the third day and the fourth day is significant, though not as significant as the difference between the first day and the second day. The composition ratio of litters was compatible with bins. It has been found that misusers of bins either didn't look at bins or looked only a moment, whereas responsible users looked bins more than one second.

\begin{tabular}{|l|c|l|l|l|c|c|}
\hline & $\begin{array}{l}\text { Ideal } \\
\text { Recycle }\end{array}$ & $\begin{array}{l}\text { Real } \\
\text { Recycle }\end{array}$ & $\begin{array}{l}\text { Ideal } \\
\text { Waste }\end{array}$ & $\begin{array}{l}\text { Real } \\
\text { Waste }\end{array}$ & $\begin{array}{l}\text { E.D.C } \\
\cdot\end{array}$ & $\begin{array}{l}\text { Sample } \\
\text { Size }\end{array}$ \\
\hline $\begin{array}{l}\text { First } \\
\text { Day }\end{array}$ & $64.70 \%$ & $14.70 \%$ & $35.29 \%$ & $35.29 \%$ & None & 34 \\
\hline $\begin{array}{l}\text { Second } \\
\text { Day }\end{array}$ & $78.94 \%$ & $63.15 \%$ & $21.05 \%$ & $10.53 \%$ & $\begin{array}{c}14.28 \\
\%\end{array}$ & 19 \\
\hline $\begin{array}{l}\text { Third } \\
\text { Day }\end{array}$ & $72.72 \%$ & $54.54 \%$ & $27.27 \%$ & $4.54 \%$ & $\begin{array}{c}29.41 \\
\%\end{array}$ & 22 \\
\hline $\begin{array}{l}\text { Fourth } \\
\text { Day }\end{array}$ & $58.82 \%$ & $26.47 \%$ & $41.17 \%$ & $23.52 \%$ & $40 \%$ & 34 \\
\hline
\end{tabular}

Table 1: Percentages of Different Experiments.

\begin{tabular}{|l|c|c|c|}
\hline & \multicolumn{2}{|c|}{ Recycle Bins } & \\
\hline & $\begin{array}{l}\text { Recyclable } \\
\text { Material }\end{array}$ & $\begin{array}{l}\text { Non-recyclable } \\
\text { Material }\end{array}$ & $\begin{array}{l}\text { Unidentified } \\
\text { Material }\end{array}$ \\
\hline First Day & 5 & None & None \\
\hline Second Day & 11 & 2 & 1 \\
\hline Third Day & 10 & 5 & 2 \\
\hline Fourth Day & 8 & 6 & 1 \\
\hline Waste Bins & \multicolumn{2}{|c|}{$\begin{array}{c}\text { Unidentified } \\
\text { Recyclable }\end{array}$} & $\begin{array}{l}\text { Non-recyclable } \\
\text { Material }\end{array}$ \\
\hline First Day & 17 & 6 & 6 \\
\hline Second Day & 3 & 2 & None \\
\hline Third Day & 4 & 1 & None \\
\hline Fourth Day & 11 & 7 & 1 \\
\hline
\end{tabular}

Table 2: Numbers and Classifications of Usages.

Our study is compatible with previous findings that the closest bins were preferred more by their participants. Although the population of the university is predominately female, and girls and women have higher tendency to recycle [29-31] and recycling behavior is closely associated to higher education [31-34], the significant difference of misplaced litters on the first and on the third day indicates a robust finding of the present research beside that younger people tend to recycle less $[30,35,36]$ weakens the research. Similar to [19], which found that separating recyclable materials into so many categories discourages $20 \%$ of respondents to recycle, our study observed that people throw their litter into the nearest bin whether recyclable or not, even if all unidentified litters were thrown into the correct bin (Table
2). In view of this finding, we may optimize the process of recycling due to people's tendency to use the nearest bin, without creating new costs. This regulation might eliminate or at least reduce the problem that we cannot obtain all recyclable materials even in most developed regions [37]. The first choice is placing bins on the $y$ axis, though our findings show that placement on the $\mathrm{x}$ axis also works, if less effectively.

\section{Conclusion}

Placing bins on the $y$ axis when the foot traffic is on $\mathrm{x}$ axis is the most efficacious method. In this method, bins' relative proximity to foot traffic is the same wherever a pedestrian comes from. However, it may not sometimes be possible, to place bins on the y axis, because of the architectural inconvenience of the building or the lack of usable space. In this case, the second most effective method can be used: placing bins on the $\mathrm{x}$ axis, when the foot traffic is on the $\mathrm{x}$ axis. It is suggested that in places with higher amounts of recyclable material, recycling bins to be placed nearer, regardless of externally derived contamination, in order to obtain as much recyclable material possible. Obtained amount of recyclable material can offset the amount of externally derived contamination. Placing bins on the $y$ axis should be the primary choice. Limitations of this study may be: universities provide mostly educated population that may differ in recycling behaviors outside the campus, this possible difference may provide different results. Also, the bins in this study were nearly identical, all bins had grey color. The results may be improved further with colored recycling bins. Different shapes and colors might affect the results [38]. Future studies can investigate the parameters a bin possess that can influence recycling behavior and also can replicate the study. We also suggest more emphasis on the importance of recycling in education for the future of our planet.

\section{Acknowledgement}

We would like to express our debt of gratitude to Prof. Kenneth R. Westphal for helping and advising us in the matters of language and teaching how to write better.

\section{References}

1. Armijo-de VC, Ojeda-Benítez, S, Aguilar-Virgen Q, Taboada-González PA (2010) Solid waste management in a Mexican university using a community-based social marketing approach. The open waste management journal 3: 146-154.

2. Brothers KJ (1994) Office paper recycling: A function of container proximity. J Appl Behav Anal 27: 153-160.

3. Buwalda T (2001) Plastics. The McGraw-Hill recycling handbook. McGraw-Hill, New York.

4. Charmaz K (2006) Constructing grounded theory: A practical guide through qualitative analysis (Introducing Qualitative Methods Series).

5. Ferrer-Balas D, Buckland H, Mingo M (2009) "Explorations on the University's role in society for sustainable development through a systems transition approach. Case-study of the technical University of Catalonia (UPC)". J Cleaner Prod 17: 1075-1085.

6. Davies J, Foxall G R, Pallister J (2002) Beyond the intention-behavior mythology an integrated model of recycling. Marketing theory 2: 29-113.

7. Diamond WD, Loewy BZ (1991) Effects of Probabilistic Rewards on Recycling Attitudes and Behavior. Journal of Applied Social Psychology 21: 1590-1607.

8. Emery AD, Griffiths AJ, Williams KP (2003) An in depth study of the effects of socio-economic conditions on household waste recycling practices. Waste Manag Res 21: 180-190. 
Citation: Aras FK, Anarat C (2016) Relative Location of Bins and Its Effects on Recycling in Campus. Int J Waste Resour 6: 220. doi:

Page 4 of 4

9. Evison T, Read AD (2001) Local Authority recycling and wasteawareness publicity/promotion. Resources, Conservation and Recycling 32: 275-291.

10. Zilahy G, Huisingh D (2009) "The roles of academia in Regional Sustainability Initiatives”. J Cleaner Prod 17: 1057-1066.

11. Geller ES, Chaffee JL, Ingram RE (1975) Promoting paper recycling on a university campus. Journal of Environmental Systems 5: 39-57.

12. Goffman E (1959) The moral career of the mental patient. Psychiatry 22: 123-142.

13. Goldenhar LM, Connell CM (1992) Effects of educational and feedback interventions on recycling knowledge, attitudes, beliefs, and behaviors. Journal of Environmental Systems 21: 321-321.

14. Guerin D, Crete J, Mercier J (2001) A multilevel analysis of the determinants of recycling behavior in the European countries. Social Science research 30: 195-218.

15. Hamburg KT, Haque CE, Everitt JC (1997) Municipal waste recycling in Brandon, Manitoba: Determinants of participatory behaviour. The Canadian Geographer/Le Géographe canadien 41: 149-165.

16. Hornik J Cherian J Madansky M Narayana C (1995) Determinants of recycling behavior: A synthesis of research results. The Journal of SocioEconomics 24: 105-127.

17. Jesson J K, Stone I (2009) A review of barriers to kerbside recycling household waste in the UK.

18. Kalatzi IK, Nikellis AE, Menegaki AN, Tsagarakis KP (2015) The preferred bin colour for recycling plastic bottles: evidence from a student's sample. Progress in Industrial Ecology, an International Journal 9: 256-268.

19. Katzev R, Mishima HR (1992) The use of posted feedback to promote recycling. Psychological Reports 71: 259-264.

20. Kelly TC, Mason IG, Leiss MW, Ganesh S (2006) "University community responses to on-campus resource recycling". Resources, Conservation and Recycling 47: 42-55.

21. Velázquez L, Munguia N, Platt A, Taddei J (2006) Sustainable University: what can be the matter? J. Cleaner Prod 14: 810-819.

22. Luyben PD, Cummings S (1981) Motivating beverage container recycling on a college campus. Journal of Environmental Systems 11: 235-245.

23. Juárez-Najera M, Dieleman H, Turpin-Marion S (2006) "Sustainability in Mexican Higher Education: towards a new academic and professional culture". J Cleaner Prod 14: 1028-1038.

24. Lehmann M, Christensen P, Thrane M, Jørgensen TH (2009) "University engagement and regional sustainability initiatives: some Danish experiences". University engagement and regional sustainability initiatives: some Danish experiences 17: 1067-1074.

25. Martin M, Williams ID, Clark M (2006) Social, cultural and structural influences on household waste recycling: a case study. Resources, conservation and recycling 48: 357-395.

26. McCarty JA, Shrum LJ (1994) The recycling of solid wastes: Personal values, value orientations, and attitudes about recycling as antecedents of recycling behavior. Journal of Business Research 30: 53-62.

27. Meneses GD, Palacio AB (2005) Recycling behavior a multidimensional approach. Environment and Behavior 37: 837-860.

28. Nixon H, Saphores JDM (2009) Information and the decision to recycle: results from a survey of US households. Journal of environmental planning and management 52: 257-277.

29. Oskamp S (1995) Resource conservation and recycling: Behavior and policy. Journal of Social Issues 51: 157-177.

30. Saphores JDM, Nixon H, Ogunseitan OA, Shapiro AA (2006) Household willingness to recycle electronic waste an application to California. Environment and Behavior 38: 183-208.

31. Schneider D, Ragossnig A (2014) Impacts and limitations of recycling. Waste Manag Res 32: 563-564.

32. Schultz PW, Bator RJ, Large LB, Bruni CM, Tabanico JJ (2011) Littering in context: Personal and environmental predictors of littering behavior. Environment and Behavior.

33. Shao G, Liang J (2010) An Analysis on the Effect of Supermarket Experiential Marketing Impacting Customer Loyalty.

34. Smyth DP, Fredeen AL, Booth AL (2010) Reducing solid waste in higher education: The first step towards 'greening'a university campus. Resources, Conservation and Recycling 54: 1007-1016.

35. Sowada C (2006) The Polish Health System in Europe: Situation, Reforms and Challenges. The New Generations of Europeans: Demography and Families in the Enlarged European Union.

36. Tonglet M, Phillips PS, Read AD (2004) Using the Theory of Planned Behaviour to investigate the determinants of recycling behaviour: a case study from Brixworth, UK. Resources, Conservation and Recycling 41: 191-214.

37. Vining J, Ebreo A (1990) What makes a recycler? A comparison of recyclers and nonrecyclers. Environment and behavior 22: 55-73.

38. Witmer JF, Geller ES (1976) Facilitating paper recycling: effects of prompts, raffles, and contests. J Appl Behav Anal 9: 315-322. 